\title{
PRELIMINARY STUDIES ON DEVELOPMENT OF A NEW ENVIRONMENTALLY FRIENDLY PLANT PROTECTION PRODUCT AGAINST GREY MOULD
}

\author{
Valda Laugale*, Lìga Jankevica**, Ineta Samsone**, Jūlija Haḷimona**, Rita Sešḳēna**, \\ Zane Metla ${ }^{* *}$, Jānis Lepsis*, Regina Rancāne ${ }^{\star * *}$, and Māris Daugavietis ${ }^{\star * * *}$ \\ * Pūre Horticultural Research Centre, Abavas iela 2, Pūre, Tukuma nov., LATVIA; \\ valda.laugale@puresdis.Iv \\ ** Institute of Biology, University of Latvia, Miera iela 3, Salaspils, LATVIA; \\ jankevica.liga@inbox.Iv \\ *** Latvian Plant Protection Research Centre, Struktoru iela 14a, Rīga, LATVIA; \\ regina.rancane@laapc.Iv \\ **** Latvian State Forest Research Institute "Silava", Rĩgas iela 111, Salaspils, LATVIA; \\ maris.daugavietis@silava.Iv
}

Communicated by Zinta Gaile

\begin{abstract}
The development of new environmentally friendly plant protection products against grey mould disease (caused by Botrytis cinerea Pers.) was started in 2010. In the Latvian State Forest Research Institute "Silava", production of coniferous biomass extracts using different solvents for extraction was performed. During 2010-2011, several laboratory investigations were carried out in the Institute of Biology, University of Latvia. Effectiveness of pine (Pinus sylvestris) and spruce (Picea abies) biomass extracts against Botrytis cinerea was tested. On the basis of coniferous extracts, 11 formulations were created and characterised. The effect of the formulations on mycelial growth of B. cinerea test cultures was tested using the fungal radial growth test. All formulations had inhibitory effect on mycelium growth (inhibition rate over 50\%) at concentration $20 \mathrm{~g} \mathrm{~L}^{-1}$ in medium. The impact of formulations on plants after spraying was evaluated using in vitro propagated strawberry plants. Chlorophyll content and chlorophyll fluorescence were estimated. Extracts did not show negative effect on the chlorophyll content and fluorescence of strawberry leaves. Field investigations on strawberry (Fragaria $\times$ ananassa Duch.) 'Senga Sengana' and primocane raspberry (Rubus idaeus) 'Gerakl' were conducted in the Püre Horticultural Research Centre in 2011. None of tested the coniferous biomass extract formulations showed higher effec-

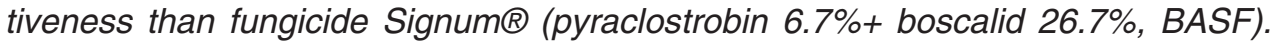

Key words: Botrytis cinerea, strawberry, inhibition of fungi, raspberry, pine biomass extract, spruce biomass extract.

Grey mould (caused by the fungal pathogen Botrytis cinerea Pers.) is one of the most important diseases of berry crops. Most of the fungicides that have been recently developed for $B$. cinerea control are site-specific inhibitors with a high risk for resistance development.

The aims of our studies were to develop different pine ( $P i$ cea abies) and spruce (Pinus sylvestris) biomass extract formulations and to test their effectiveness against grey mould (Botrytis cinerea Pers.) in berry crops.

The study was started in 2010. Four coniferous extracts (spruce biomass ethanol extract, spruce biomass $\mathrm{Na}_{2} \mathrm{CO}_{3}$ extract, pine biomass ethanol extract and pine biomass $\mathrm{NaOH}$ extract) were produced and characterised in the Lat- vian State Forest Research Institute "Silava". Laboratory investigations were conducted in the Institute of Biology, University of Latvia in 2010-2011. Eleven formulations of coniferous biomass extracts were developed (Table 1). Formulations consisted of active substances: $20 \%$ coniferous tree biomass extract, $10 \%$ binding agent - calcium carbonate (OMYA, ES) or glycerol anhydrous (Penta, Czech Republic), emulsifiers Tween-80 (Scharlau, Spain) or Trifolio $\mathrm{S}$ - Forte (Trifolio-M GmbH, Germany) and additional substances (water and 96\% alcohol).

The inhibiting effect of extracts was evaluated on three $B o$ trytis cinerea strains: B. cinerea strain LMSC No. 658, obtained in Latvia in 2002, supplied from the National Microbial Strain Collection of Latvia; and B. cinerea strains 
DESCRIPTION OF FORMULATIONS DEVELOPED FROM CONIFEROUS BIOMASS EXTRACTS

\begin{tabular}{|c|c|c|c|c|}
\hline No. & Coniferous biomass extract & Binding agent & Emulsifier & $\begin{array}{c}\text { Concentration } \\
\text { used for spraying, } \%\end{array}$ \\
\hline No. 1 & spruce biomass extract AAL1 & $*$ & $*$ & 2 \\
\hline No. 2 & spruce biomass ethanol extract & calcium carbonate & Tween-80 & 2 \\
\hline No. 3 & spruce biomass ethanol extract & glycerol & Tween-80 & 2 \\
\hline No. 4 & spruce biomass $\mathrm{Na}_{2} \mathrm{CO}_{3}$ extract & & Tween-80 & 2 \\
\hline No. 5 & spruce biomass $\mathrm{Na}_{2} \mathrm{CO}_{3}$ extract & calcium carbonate & Tween-80 & 2 \\
\hline No. 6 & spruce biomass $\mathrm{Na}_{2} \mathrm{CO}_{3}$ extract & glycerol & Tween-80 & 2 \\
\hline No. 7 & pine biomass extract AAL2 & $*$ & $*$ & 1 \\
\hline No. 8 & pine biomass ethanol extract & calcium carbonate & Trifolio S - Forte & 1 \\
\hline No. 9 & pine biomass $\mathrm{NaOH}$ extract & & Trifolio S - Forte & 2 \\
\hline No. 10 & pine biomass $\mathrm{NaOH}$ extract & calcium carbonate & Trifolio S - Forte & 2 \\
\hline No. 11 & pine biomass $\mathrm{NaOH}$ extract & glycerol & Trifolio S - Forte & 2 \\
\hline
\end{tabular}

* Parts of formulations AAL1 and AAL2 will be included in patent proposal

LUBI-3A and LUBI-4B, obtained from infected plant material, collected from the Pūre Horticultural Research Centre in 2010. Fungal isolates were cultivated and maintained on Potato Dextrose Agar medium (PDA). Inhibitory activity of the developed formulations was tested. Eleven formulations, described above, were added to a sterile molten PDA medium to obtain final concentration of $20 \mathrm{~g} \mathrm{~L}^{-1} ; 10 \mathrm{~g} \mathrm{~L}^{-1}$; $1 \mathrm{~g} \mathrm{~L}^{-1}$ and $0.1 \mathrm{~g} \mathrm{~L}^{-1}$ in media. As a negative control, PDA with $20 \mathrm{~g} \mathrm{~L}^{-1}$ Bordeaux mix (Karaleks Ltd., Latvia) was used and as a positive control - PDA without any additions. An agar plug with five-day-old mycelium was placed in the middle of each Petri dish. Inoculated dishes were incubated at $25 \pm 1{ }^{\circ} \mathrm{C}$. Five replicates were used. Mycelium measurements were started on the first day after beginning of the experiment and were carried out every $24 \mathrm{~h}$. The percentage of mycelial growth inhibition $(\mathrm{P})$ at each concentration was calculated according to the following formula: $\mathrm{P}(\%)=$ [DC-DT] / DC] 100, where DC and DT are the average diameters of fungal colony of control and treatment, respectively (Pandey et al., 1982). The influence of four coniferous biomass extracts on plant photosynthetic parameters was evaluated on strawberry (Fragaria $x$ ananassa Duch.) plants 'Senga Sengana', propagated in vitro. Plantlets were removed from the medium and planted into plastic pots containing commercial peat with mineral nutrients. Plants were kept in a growth chamber at $25^{\circ} \mathrm{C}$, photoperiod $18 \mathrm{~h}$, relative humidity about $60 \%$. Light was provided by fluorescent lamps with $200 \mu \mathrm{mol} \mathrm{m} \mathrm{m}^{-2} \mathrm{~s}^{-1}$ light intensity. Two-month-old plants were used for the experiment. Water suspensions of each of four coniferous extracts ( $2 \%$ concentration) were sprayed on ten plants. Control plants were sprayed with distilled water. Chlorophyll content and chlorophyll fluorescence were measured for ten leaflets of middle aged leaves, from different plants, at five times (1st, 2nd, 7th, 17th, and 22nd days after treatment). Chlorophyll $\alpha$ fluorescence was measured on the abaxial side of the leaves by a fast fluorometer PEA (Hansatech, England). The leaves were placed into clips, maintained in the dark for 20 min and then illuminated for $5 \mathrm{~s}$ with red diodes (peak 650 $\mathrm{nm}$, maximum PPFD at leaf surface was $3000 \mu \mathrm{mol} \mathrm{m} \mathrm{s}^{-2}$ ). Samples were characterised by the parameter Fv/Fm. Chlorophyll content was measured with a SPAD-502 chlorophyll metre (Konica-Minolta, Osaka, Japan). Five to ten consecutive readings were made across the surface of each leaf. Mean value was calculated using the internal function of the chlorophyll metre. The results were compared using the Student's t-test (level of significance: $P=0.05$ ).

Field investigations were performed in the Pūre Horticultural Research Centre (GPS: $57^{\circ} 02^{`} \mathrm{~N}$; $22^{\circ} 52^{`} \mathrm{E}$ ) in 2011 on three-year-old strawberry plants, cultivar 'Senga Sengana', and six years old primocane raspberry (Rubus idaeus) plants, cultivar 'Gerakl'. Strawberries were grown in 20 wide matted rows with one metre distance between rows, without any mulching and irrigation. Primocane raspberries were grown in hedgerows with $2.7 \mathrm{~m}$ distance between hedgerows, without any mulching and irrigation. All eleven coniferous extract formulations (Table 1) were sprayed on strawberry plants four times at one-week intervals, starting from the beginning of flowering (May 24), till the beginning of harvesting (June 14). Nine formulations (No. 1, 2, 3, 4, 5, 6, 9, 10, 11) were sprayed on raspberry plants five times at one week intervals from the beginning of flowering (July 13) till the beginning of harvesting (August 10). Additional control treatment with no plant protection products and a chemical control treatment with fungicide Signum ${ }^{\circledR}$ (pyraclostrobin $6.7 \%+$ boscalid 26.7\%, BASF) were applied two times during flowering at two week intervals, with dose $1.8 \mathrm{~kg} \mathrm{ha}^{-1}$. Treatments were performed in three replicates and test plots were located randomly. The growing season was characterised by higher average air temperatures and lower amount of precipitations, compared with long-term observations. In both trials the yield was harvested two to three times weekly. Rotten fruits were counted separately and the percentage of rotten fruits was calculated. One way ANOVA and Duncan's multiple range test were used to determine the differences among treatments $(P=0.05)$. Percentages were arcsine transformed prior to statistical analysis. 
INHIBITION OF MYCELIAL GROWTH OF Botrytis cinerea STRAINS IN RADIAL GROWTH TESTS, RECORDED THREE DAYS AFTER INOCULATION ON MEDIUM WITH PLANT EXTRACT FORMULATIONS

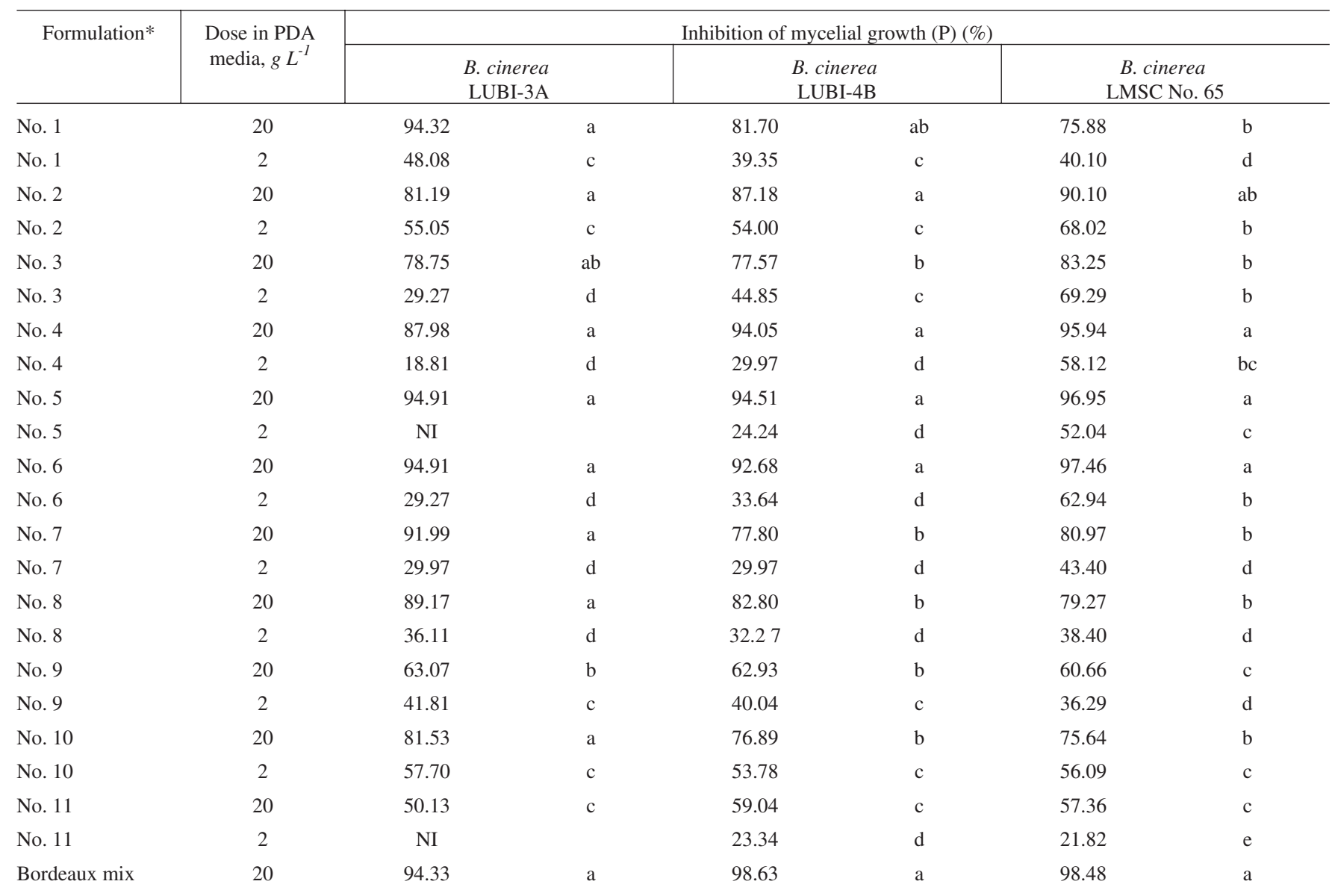

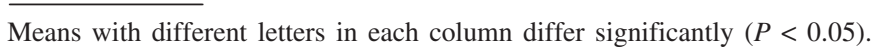

* Formulations added to PDA: No. 1 - spruce biomass extract AAL1**; No. 2 - spruce biomass ethanol extract with calcium carbonate as binding agent and emulsifier; No. 3 - spruce biomass ethanol extract with glycerol as binding agent and emulsifier; No. 4 - spruce biomass $\mathrm{Na}_{2} \mathrm{CO}_{3}$ extract with emulsifier; $\mathrm{No}_{\text {. }}$ 5 - spruce biomass $\mathrm{Na}_{2} \mathrm{CO}_{3}$ extract with calcium carbonate as binding agent and emulsifier; $\mathrm{No}^{6}$ - spruce biomass $\mathrm{Na}_{2} \mathrm{CO}_{3}$ extract with glycerol as binding agent and emulsifier; No. 7 - pine biomass extract AAL2**; No. 8 - pine biomass ethanol extract with calcium carbonate as binding agent and emulsifier; No. 9 - pine biomass NaOH extract with emulsifier; No. 10 - pine biomass NaOH extract with calcium carbonate as binding agent and emulsifier; No. 11 pine biomass $\mathrm{NaOH}$ extract with glycerol as binding agent and emulsifier. NI, inhibitions of fungal growth was not observed; some of the formulations will be included in patent proposals.

The radial test showed that all tested coniferous extract formulations added to nutrient media had effect on mycelial growth of $B$. cinerea isolates (Table 2). Higher concentrations significantly increased the inhibitory effect. All formulations had inhibitory effect on mycelium growth (growth inhibition over 50\%) at dose $20 \mathrm{~g} \mathrm{~L}^{-1}$ in medium. Michaelis et al. (2012) reported that ethanolic fractions of Chilean plant extracts had inhibitory effect on mycelial growth of $B$. cinerea at dose $0.25 \mathrm{~g} \mathrm{~L}^{-1}$. The growth of $B$. cinerea isolates was significantly inhibited using formulations No. 1, 2, 4, 5, 6, 7 and 10 at dose $20 \mathrm{~g} \mathrm{~L}^{-1}$. Inhibitory effect of the tested formulations at dose $2 \mathrm{~g} \mathrm{~L}^{-1}$ was significantly lower than inhibition caused by a Bordeaux mix $(P<$ 0.05). Only formulations No. 2 and 10, at dose $2 \mathrm{~g} \mathrm{~L}^{-1}$, had inhibitory effect on $B$. cinerea (growth inhibition over $50 \%$ ). Formulation No. 11 showed the lowest percentage growth inhibition among all concentrations.
The effect of coniferous biomass extracts on physiological processes in strawberries was studied in the Institute of Biology, University of Latvia. It has been reported that conifers produce many compounds that might influence growth of other plants (Aliloo et al., 2012). Pine needle extracts have phytotoxic effect on several plants. Inhibitory compounds are substances that hinder photosynthesis (Nektarios et al., 2005). However, according to our findings, none of the coniferous biomass extracts used for treatment of plants showed any negative effect on plant chlorophyll fluorescence ratio $\mathrm{Fv} / \mathrm{Fm}$, which is used as a stress indicator and describes the potential yield of the photochemical reaction. The results showed that the value of chlorophyll fluorescence (parameter $\mathrm{F}_{\mathrm{v}} / \mathrm{F}_{\mathrm{m}}$ ) was above 0.85 in all variants, indicating high potential activity of photosystem II. It is known that coniferous needle extract "Ausma" has positive effect on strawberry development - plant total weight, 
crown diameter and leaf number (Laugale et al., 2006). We found positive effect of pine biomass ethanol extract on the amount of chlorophyll in strawberry leaves $(P<0.05)$. However, the chlorophyll content of leaves treated with pine biomass $\mathrm{NaOH}$ extract, spruce biomass ethanol extract and spruce biomass $\mathrm{Na}_{2} \mathrm{CO}_{3}$ extract did not differ from that of control plants. Zarins and Daugavietis (1998) observed that tomato leaves treated with pine and spruce needle phytopreparation "Fitoekols IF" did not differ in the amount of chlorophyll in treated and nontreated plants. Our results indicated that none of the coniferous extracts used for treatment of plants had negative effect on plant photosynthetic parameters, and thus they can be recommended for use in plant protection.

While laboratory experiments showed that coniferous biomass extract formulations significantly inhibited $B$. cinerea mycelial growth, they did not demonstrate high effectiveness in field investigations. The growing season was rather warm and dry and spread of grey mould was not successful. The percentage of rotten fruits in strawberry field trials varied from 5 to $10 \%$ of the total amount, and did not differ significantly $(P>0.05)$ from the control. A lower proportion of rotten fruits, in comparison to the control, was observed in the treatments where spruce biomass formulations No. 4, 2, 3, 1 and pine biomass formulations No. 11 and 10 were applied. In the treatment with fungicide Signum® was applied, the percentage of rotten fruits was $2 \%(P<0.05)$. Pine biomass formulations No. 7 and 8 showed the lowest effectiveness and were not tested on raspberry plants. In the field experiment on primocane raspberry, the percentage of rotten fruits varied from 5 to $14 \%$ of the total amount, depending on the treatment. The highest effectiveness was observed when fungicide Signum ${ }^{\circledR}$ was applied. Spruce biomass formulations No. 6, 1, 2 and pine biomass formulation
No. 11 were the most effective among all coniferous formulations.

None of tested coniferous formulations showed higher effectiveness against grey mould in the field, than chemical control by fungicide Signum ${ }^{\circledR}$. For both crops the most efficient coniferous preparations were spruce biomass extract AAL1, spruce biomass ethanol extract with calcium carbonate as binding agent and emulsifier, and pine biomass $\mathrm{NaOH}$ extract with glycerol as binding agent and emulsifier, all applied in $2 \%$ concentration. Due to unconvincing results, more field investigations on effectiveness are necessary.

This study was supported by the ERDF project No. 2010/ 0249/2DP/2.1.1.1.0/10/APIA/VIAA/168 "Development of environment-friendly plant protection products from conifer tree biomass extractives".

\section{REFERENCES}

Aliloo, A. A., Shahabivand, S., Farjam, L., Heravi, S. (2012). Allelopathic effects of pine needle extracts on germination and seedling growth of ryegrass and Kentucky bluegrass. Adv. Environ. Biol., 6 (9), 2513-2518.

Laugale, V., Lepse, L., Daugavietis, M. (2006). Using of growth stimulator "Ausma" in strawberry plant production. Latvian J. Agron., 9, 64-68.

Michaelis, V. S., Apablara-Hidalgo, A., Gomez, M., Pena-Vera, R., Montenegro, G. (2012). Antifungal activity of three Chilean plant extracts on Botrytis cinerea. Bot. Sci., 90 (2), 179-183.

Nektarios, P. A., Economou, G., Avgoulas, C. (2005). Allelopathic effects of Pinus halepensis needles on turfgrasses and biosensor plants. Hort. Sci., 40 (1), 246-250.

Pandey, D. K., Tripathi, N. N., Tripathi, R. D., Dixit, S. N. Z. (1982). Fungitoxic and phytotoxic properties of essential oil of Hyptis suaveolens. Pfl. Krankh Pfl. Schutz, 89, 344-349.

Zarins, I., Daugavietis, M. (1998). Conifer foliage extractive substances in plant protection. Baltic For., 4 (2), 31-39.

\section{SĀKOTNĒJIE PĒTĪJUMI PAR JAUNA, VIDEI DRAUDZĪGA AUGU AIZSARDZĪBAS LĪDZEKLA IZSTRĀDI PRET PELĒKO PUVI}

Jauna, videi draudzīga augu aizsardzības līdzekḷa izstrāde pret pelēko puvi tika uzsākta 2010. gadā. Latvijas valsts Mežzinātnes Institūtā "Silava" iegūti un raksturoti četri kokaugu biomasas ekstrakti. Laikā no 2010. gada līdz 2011. gadam Latvijas Universitātes Bioloğijas institūtā veikti laboratorijas izmēǵinājumi, lai noteiktu dažādu priedes (Pinus sylvestris) un egles (Picea abies) biomasas ekstraktu efektivitāti pret Botrytis cinerea. Uz skujkoku ekstraktu bāzes izveidotas un raksturotas 11 dažādas preparatīvās formas. Preparatīvo formu efektivitāte pārbaudīta, izmantojot sēṇu radiālās augšanas testu, lai noskaidrotu to ietekmi uz $B$. cinerea izolātu micēlija augšanu. Visas preparatīvās formas, pievienojot barotnei $20 \mathrm{~g} \mathrm{~L}^{-1}$ koncentrācijā, samazināja micēlija augšanu (samazinājums vairāk kā $50 \%$ ). Tika arī vērtēta preparatīvo formu ietekme uz augiem pēc smidzināšanas, izmantojot in vitro pavairotos stādus. Noteikts hlorofila saturs un fluorescence. Ekstrakti būtiski neietekmēja hlorofila saturu zemeņu lapās. Pūres Dārzkopības pētījumu centrā 2011. gadā veikti lauka izmēǵinājumi uz zemeņu (Fragaria $\times$ ananassa Duch.) šķirnes 'Senga Sengana' un rudens avenes (Rubus idaeus) 'Gerakl'. Neviena no vērtētajām skujkoku preparatīvajām formām neuzrādīja augstāku efektivitāti kā fungicīds Signum® (piraklostrobīns $6.7 \%+$ boskalīds $26.7 \%$, BASF). 